\title{
In memoriam \\ Dr. Jaime Villalba Caloca (1928-2020)
}

\author{
In memoriam \\ Jaime Villalba Caloca, MD (1928-2020)
}

Patricio Santillán-Doherty*

*Instituto Nacional de Enfermedades Respiratorias Ismael Cosío Villegas. Ciudad de México, México.

El miércoles 18 de noviembre de 2020, en plena pandemia por el virus SARS-CoV-2, pero por causas no relacionadas, falleció el Dr. Jaime Villalba Caloca, figura paradigmática del Instituto Nacional de Enfermedades Respiratorias, de la Facultad de Medicina de la UNAM, así como un líder indiscutible de la Neumología y la Cirugía Torácica de nuestro país. El acontecimiento fue anunciado durante la conferencia vespertina que cotidianamente ofrecen las autoridades de la Secretaría de Salud en el Palacio Nacional con objeto de revisar la situación que guarda la pandemia.

Con una trayectoria de 62 años, es un ejemplo de la importancia de mantener una estructura profesional integrada como clínico, investigador y docente; simplemente no concebía la falsa idea de una división instrumentalizada de las actividades del médico en la que, por criterios de conveniencia administrativo-burocrático, se pretende tricotomizar su quehacer profesional en atención, ciencia o enseñanza.

Fue integrante del grupo multidisciplinario que realizó el primer trasplante pulmonar en 1989 en el país y en América Latina. En su trayectoria dentro del INER fue cirujano, jefe del Departamento de Cirugía y Cirugía Experimental, Director de Enseñanza y luego Director General en el período 1993-2003. Y al terminar su cargo directivo se reintegró a su

Correspondencia:

Dr. Patricio Santillán-Doherty

Dirección Médica. Instituto Nacional de Enfermedades Respiratorias Ismael Cosío Villegas.

Correo electrónico: patricio.santilland@gmail.com

Trabajo recibido: 28-XII-2020; aceptado: 29-XII-2020.

Citar como: Santillán-Doherty P. In memoriam Dr. Jaime Villalba Caloca (1928-2020). Neumol Cir Torax. 2020; 79 (4): 212-213. https://dx.doi. org/10.35366/97961

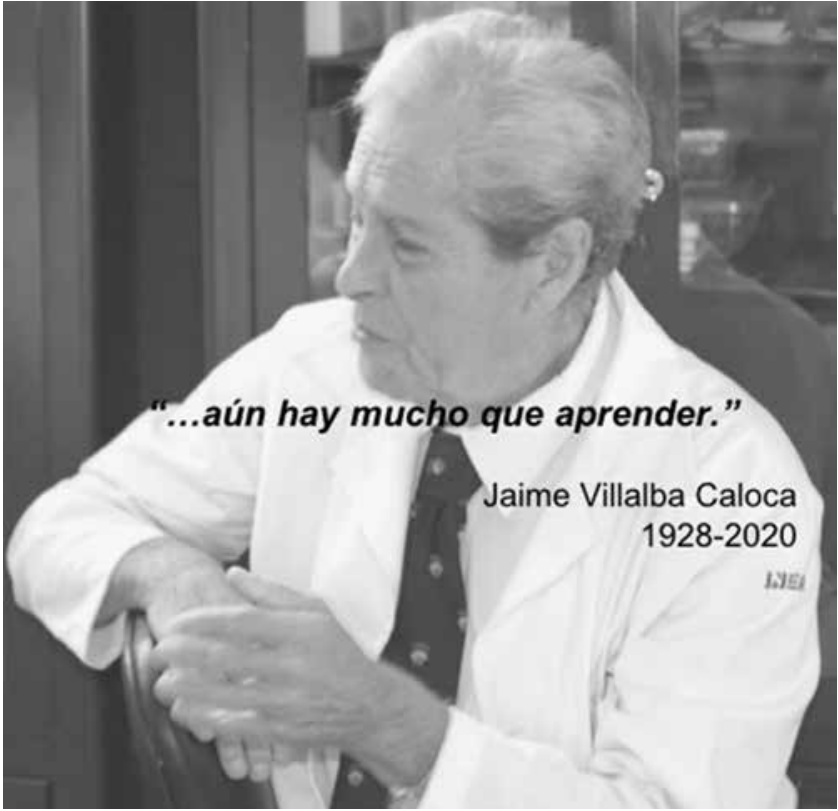

Figura 1: El Dr. Jaime Villalba Caloca, Ex-Presidente de la SMNYCT y Ex-Director del INER, falleció el 18 de noviembre de 2020.

actividad profesional como jefe de la Unidad de Trasplante Pulmonar Experimental del Departamento de Investigación en Cirugía Experimental.

Su inquietud intelectual lo llevó a inscribirse como alumno de posgrado a los ochenta años y obtener el grado de Doctor en Ciencias en 2008. Asimismo, su sensibilidad humana le impulsó a fungir como presidente del Comité Hospitalario de Bioética por más de 10 años y a difundir las ideas surgidas de las discusiones en el libro «Reflexiones Bioéticas» publicado hace poco más de un año. En la introducción el Dr. Villalba deja ver claramente el tipo de persona que es cuando 
escribe sobre lo que le importa: «...aprendiendo a responder preguntas con más preguntas, y a reconocer la importancia de la otredad» para luego citar el poema Piedra de Sol de Octavio Paz y declarar «mirarnos en el otro para poder ser nosotros» (ver reseña de Sandoval JL en NCT https://www.medigraphic.com/pdfs/neumo/ nt-2020/nt201j.pdf).

Fue miembro distinguido de la Sociedad Mexicana de Neumología y Cirugía de Tórax, de la cual llegó a ser su Presidente de 1989 a 1991. Fue docente de pregrado y posgrado en la Facultad de Medicina de la UNAM y a lo largo de su carrera realizó más de 100 publicaciones en revistas de nuestro país y el extranjero, 17 capítulos de libro, 19 editoriales y 74 resúmenes de trabajos presentados en congresos nacionales y extranjeros. Asimismo, fue miembro del Subcomité Académico de Cirugía Cardiovascular y Torácica, y Coordinador del Subcomité Académico de Neumología del Programa Único de Especializaciones Médicas.

También fue reconocido con el Premio Nacional de Administración Pública 1989 y con el de la Excelencia Médica por ser pionero en el campo de trasplantes de órganos y tejidos en México en el Siglo XX; y, como ejemplo de su persistencia, su nombre se encuentra ligado en 11 ocasiones al Premio Nacional de Cirugía «Dr. Francisco Montes de Oca» que otorga anualmente la Academia Mexicana de Cirugía de la que fue miembro emérito (i11 premios en 35 años!). Además, fue miembro de la Academia Nacional de Medicina de México.

En la sesión In memoriam realizada a una semana de su deceso, el 25 de noviembre de 2020, en el Auditorio Fernando Rébora del INER, quedó claro que quienes lo conocimos y tuvimos el privilegio de interactuar con él, reconocemos en su persona a un líder, un maestro y un mentor (https://www.youtube.com/watch?v=T2a9W1GGfGM). Sin embargo, es probablemente su bonhomía lo que más recuerda la gente que lo trató. Ante todo, Jaime Villalba es un ser cuya sencillez y verdad le otorgan un carácter de humildad honesta derivada del humus, la tierra, aterrizado; origen indudable de lo que significa ser «humano».

En este año epidemiológicamente complicado, su ausencia nos afecta y su partida hace recordar las palabras que Sabines le reclama a su padre: «Algo le falta al mundo y tú te has puesto a empobrecerlo más y a hacer a solas, tus gentes tristes y tu Dios contento...».

Sin embargo, irse es el destino de todos; mejor es recordar lo bueno que nos dejó Jaime Villalba Caloca. Una persona que, incluso semanas antes de su partida, se le podía escuchar decir «hay mucho que aprender todavía». Sin duda es una persona amable, que profesa amor; amor al conocimiento, a su familia, a sus amigos, a sus colaboradores, a su Instituto, a su país. Será recordado de igual manera.

Descanse en paz.

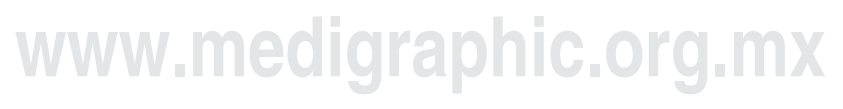

